\title{
Stress factors of nursing students in their final year
}

\author{
Fatores de estresse em estudantes do último ano da graduação em enfermagem \\ Los factores de estrés en estudiantes del último año de enfermeira
}

How to cite this article:

Mendes SS, De Martino MMF. Stress factors of nursing students in their final year. Rev Esc Enferm USP. 2020;54:e03593. doi: https://doi.org/10.1590/S1980220X2018053903593

\section{Sandra Soares Mendes ${ }^{1}$ \\ D Milva Maria Figueiredo De Martino ${ }^{1}$}

${ }^{1}$ Universidade Estadual de Campinas, Faculdade de Enfermagem, Programa de Pós-graduação em Enfermagem, Campinas, SP, Brazil.

\begin{abstract}
Objective: To identify the stress factors of the university environment and the repercussions on the quality of sleep and life of students in their last year of undergraduate nursing. Method: A cross-sectional, comparative, quantitative study conducted with students in their last year of undergraduate nursing in a private institution in the south of Minas Gerais. The Instrument for the Assessment of Stress in Nursing Students (ASNS), the Pittsburgh Sleep Quality Index (PSQI), the WHOQOL-Bref quality of life questionnaire and the sociodemographic characterization questionnaire were applied for data collection; association, comparison and correlation coefficient tests and descriptive statistics were performed for data analysis. Results: The sample consisted of 55 participants. There was a strong correlation between Time Management of stress with sleep and the physical, psychological and environmental domains of quality of life, in addition to the significant association for insomnia and some sociodemographic variables. Conclusion: Stress factors were associated with poor quality sleep and changes in quality of life. Time Management was the factor with the greatest potential for stress. The ninth semester had greater exposure to stressors, worse quality of sleep and life.
\end{abstract}

DESCRIPTORS

Students, Nursing; Stress, Psychological; Sleep; Quality of Life. 


\section{INTRODUCTION}

Nursing students face several situations that trigger stress during their professional training period, such as their initial contact with the university and autonomy in organizing schedules ${ }^{(1)}$, curricular and extracurricular activities and the internship scenario, new relationships with teachers ${ }^{(2)}$, uncertain situations and making important decisions ${ }^{(3)}$.

Some factors at the end of the undergraduate nursing course can increase stress, such as preparing reports and final papers, a feeling of insecurity and inexperience ${ }^{(4)}$, competitiveness in the job market and the fear of not engaging in professional life $f^{(4-5)}$.

The lack of adequate support to the pressures experienced in the routine of practical activities, fluctuations in work and difficulties in dealing with death are also factors which increase stress levels ${ }^{(4)}$. Nursing students working and studying with double working shifts are added to these factors, which is an unfavorable condition and can reflect on them in a harmful way, affecting their sleep quality ${ }^{(6)}$.

Studies in the international scenario have shown frequently experienced stressful situations in the nursing training environment, such as the extensive curricular load, the lack of time for academic, social, family, physical and leisure activities, personal and family problems, dissatisfaction with public transport to the locations of practical activities, inflexible hours in institutions, difficulties in relationships with classmates and professionals in the activity areas ${ }^{(7-9)}$, in addition to lowering the students' commitment level to the course in the presence of high levels of stress ${ }^{(10)}$. Results from Brazilian studies also point to similar stressors ${ }^{(2,4-5,11)}$.

Research conducted with 204 undergraduate nursing students showed that sleep quality was poor for $84.31 \%$ of the students, and those who accumulated the study/work functions had several symptoms, including: poor digestion, headache, daytime sleepiness and insomnia ${ }^{(6)}$. The results in other studies showed that students with the highest levels of stress had the worst academic results, reduced sleeping hours ${ }^{(12)}$, sleep disorders and stress-related illnesses ${ }^{(13)}$.

Therefore, sleep and quality of life can be compromised during the training period. National and international studies have shown different factors which can adversely affect the quality of life of nursing students ${ }^{(14-16)}$.

Due to the diversity of stress-generating factors in the university environment and considering the impact that stress can have on health, this study may contribute to recognizing and specifying the stress factors, especially at the end of the undergraduate nursing course, as this change may interfere with the quality of sleep and life of students. In addition, the aim is to call attention to healthcare and better use of curricular activities of students who are close to becoming nurses. Thus, this study aimed to identify the stress factors of the university environment and the repercussions on the quality of sleep and life of students in the last year of their undergraduate nursing course.

\section{METHOD}

\section{Study Design}

This is a cross-sectional comparative study implementing a quantitative approach on stress factors in the university environment and its relationship with sleep and the quality of life of students in their last year of the undergraduate nursing course.

\section{Population}

The study was developed in a private higher education institution located in the municipality of Poços de Caldas, south of Minas Gerais state, Brazil. Students in their last year of the undergraduate nursing course participated in the study. The internship schedules were conducted in the morning and afternoon. The duration of the course is five years (ten semesters). All of the 56 eligible students in their last year of the undergraduate nursing course were invited by the main researcher to participate in the study. One student in the ninth semester did not participate due to sick leave. Thus, 55 composed the final sample.

The sample was obtained from a list of students regularly enrolled in the ninth and tenth semesters provided by the secretariat of the Nursing course in the first academic semester of 2018 and who accepted to participate in the study. Students on sick leave or maternity leave were excluded from the study.

\section{SAMPLE DEFINITION}

The sample calculation was performed considering the methodology for estimating a sample size for a proportion, considering a proportion p equal to 0.50 , a sample error of $5 \%$ and a significance level of $5 \%$. The population considered for the sample size calculation was composed of 222 students. The estimated sample size was 141 students. The sample was proportionally divided according to the year the students entered.

\section{Data collection}

Data collection was carried out from May to June 2018. Students were approached in the meeting room of the internship locations on previously determined days and times by the course coordinator and internship supervision. The lead researcher and responsible for data collection explained the research objectives. Those who agreed to participate received the Free and Informed Consent Form (ICF) and after signing two copies returned one copy to the lead researcher. Next, guidance was provided on the four self-applied instruments. The average response time was approximately 20 minutes. After answering the instruments the students returned them to the main researcher, who remained at the data collection site during this time.

A questionnaire was used for the sociodemographic characterization, lifestyle and working conditions. The Instrument for the Assessment of Stress in Nursing Students (ASNS), developed and validated in Brazil, was applied for evaluating psychological stress factors. It consists of 30 items presented on a Likert scale with four points, constituted by: zero (0) for "I don't experience this situation"; one (1) for "I don't feel stressed about this situation"; two (2) for "I feel a little stressed about this situation"; and three (3) for "I feel very stressed about this situation". These items are grouped into six domains which represent stressors in the academic 
context, namely: D1 - Practical Activity Performance (PAP); D2 - Professional Communication (PC); D3 Time Management (TM); D4 - Environment (E); D5 Professional Education (PE) and D6 - Theoretical Activity (TA). The result of the stress factor assessment considers an intensity classification and the corresponding percentage of scores in each domain. The higher the score, the greater the exposure, indicating a predominance of the domain with the highest score, meaning that the items belonging to this domain have greater stress significance ${ }^{(17)}$.

The Pittsburgh Sleep Quality Index (PSQI) validated in Brazil was used to collect data on sleep. It is a questionnaire which evaluates the subjective sleep quality in the one month period directly before its application date. It contains ten self-administered questions, grouped into seven components: 1. Subjective sleep quality; 2. Sleep latency; 3. Sleep duration; 4. Habitual sleep efficiency; 5. Sleep disturbances; 6 . Use of sleeping medications; and 7. Daytime dysfunction. The score for each component ranges from zero to three points, and the overall score can vary from zero to 21 points. The higher the obtained value, the worse the assessment of sleep quality, with the overall score of five points constituting the cut-off point which enables distinguishing between subjects with poor sleep quality and sleep disorders and those with good quality sleep ${ }^{(18)}$.

The Portuguese version of the short instrument for assessing quality of life (WHOQOL-bref) was applied to obtain data on quality of life. It is a generic questionnaire on the quality of life by the World Health Organization (WHO) organized into 26 questions on a Likert-type scale, and considers the last 15 days experienced by the respondents. The first two questions "are general and refer to the perception of quality of life and satisfaction with health. The others represent the 24 facets which make up the original instrument and are divided into four domains: physical, psychological, social relations and the environment". The final score is transformed into a scale from zero to 100 , measured in a positive direction, meaning higher scores indicate greater quality of life ${ }^{(19)}$.

\section{DATA ANALYSIS AND PROCESSING}

The data were initially entered into a Microsoft Excel ${ }^{\circledast}$ spreadsheet and processed using the SAS 9.4 statistical program. The analyzes of the qualitative variables were described by frequencies and percentages, and the quantitative variables by position and dispersion measures. The Spearman's correlation coefficient was calculated to assess the relationship between the WHOQOL-bref and PSQI domains with the ASNS domains. The relationships between qualitative variables and the results of the WHOQOLbref, PSQI and ASNS instruments were assessed using the non-paired Student's t-test or the Mann-Whitney test, according to the data distribution. Data distribution was assessed using the Shapiro-Wilk test. Associations between the PSQI score classification and qualitative variables were assessed using the Chi-squared test. The significance level adopted was $5 \%$.

\section{ETHICAL ASPECTS}

Ethical considerations were respected in accordance with Resolution 466/2012 of the National Health Council and approved by the Research Ethics Committee of the Universidade Estadual de Campinas under Opinion No. 2.466.314/18.

\section{RESULTS}

The results of the sociodemographic data showed that (45.4\%) of the 55 students participating in the study were in the ninth semester and (54.6\%) were in the tenth semester, with a predominance of females (80\%), average age of 32.1 years $(\mathrm{sd}=8.15)$, without a partner $(54.5 \%)$, without children (52.8\%), and having employment activity (74.5\%). Of these, $41.8 \%$ were nursing technicians, and those in the night shift corresponded to $(36.4 \%)$. For life habits, it was found that $(61.8 \%)$ did not practice any physical activity, (72.7\%) did leisure activities, (67.3\%) did not use alcohol, (96.4\%) did not smoke and (96.4\%) did not use sleeping medications.

Regarding the quality of sleep measured by the PSQI, Table 1 illustrates a higher incidence of poor quality sleep in students in the ninth semester and in those who reported insomnia. However, no statistically significant associations were identified in relation to employment and work shift.

Table 1 - Sleep quality scores according to semester attended, reports of insomnia, employment activity and night shift - Poços de Caldas, MG, Brazil, 2018.

\begin{tabular}{|c|c|c|c|c|c|c|}
\hline \multirow{3}{*}{ Variables } & & \multicolumn{4}{|c|}{ Sleep Quality - PSQI } & \multirow{3}{*}{$p$-value } \\
\hline & & \multicolumn{2}{|c|}{ Good } & \multicolumn{2}{|c|}{ Bad } & \\
\hline & & $n$ & $\%$ & $n$ & $\%$ & \\
\hline \multirow{2}{*}{ Semester } & 9 & 3 & 12.0 & 22 & 88.0 & \multirow{2}{*}{$0.0028 *$} \\
\hline & 10 & 15 & 50.0 & 15 & 50.0 & \\
\hline \multirow{2}{*}{ Insomnia } & No & 17 & 47.2 & 19 & 52.8 & \multirow{2}{*}{$0.0016^{*}$} \\
\hline & Yes & 1 & 5.3 & 18 & 94.7 & \\
\hline \multirow{2}{*}{ Employment activity } & No & 3 & 21.4 & 11 & 78.6 & \multirow{2}{*}{$0.3457^{* *}$} \\
\hline & Yes & 15 & 36.6 & 26 & 63.4 & \\
\hline \multirow{2}{*}{ Night shift } & No & 12 & 34.3 & 23 & 65.7 & \multirow{2}{*}{$0.7445^{*}$} \\
\hline & Yes & 6 & 30.0 & 14 & 70.0 & \\
\hline
\end{tabular}

* p-value obtained using the Chi-squared test.

** p-value obtained by Fisher's exact test. 
Table 2 shows data on the relationship between stress factors and sleep, and quality of sleep and life. The results demonstrated a significant positive relationship and a strong magnitude of the physical, psychological and environmental domains of the WHOQOL-bref, PSQI score with the Time Management domain (D3), as well as a significant negative and moderate correlation of these same domains of the WHOQOL-bref and PSQI score with most ASNS domains.

Table 2 - Correlation between the scores of the quality of life and sleep domains with the stress scores - Poços de Caldas, MG, Brazil, 2018.

\begin{tabular}{lccccc}
\hline \multirow{2}{*}{ ASNS domains } & \multicolumn{2}{c}{ WHOQOL-bref domains } & \multirow{2}{*}{ PSQI score } \\
\cline { 2 - 4 } D1 (PAP) & Physical & Psychological & Social & Environment & 0.3872 \\
& -0.3718 & -0.4448 & -0.2024 & 0.3371 & 0.0035 \\
D2 (PC) & 0.0052 & 0.0007 & 0.1384 & 0.0118 & 0.3449 \\
& -03676 & -4021 & -0.209 & -0.325 & 0.0099 \\
D3 (TM) & 0.0058 & 0.0023 & 0.1257 & 0.0155 & 0.5418 \\
& -0.529 & -05037 & -0.2278 & -0.5176 & $<0.0001$ \\
D4 (E) & $<0.0001$ & $<0.0001$ & 0.0945 & $<0.0001$ & 0.2082 \\
& -0.4371 & -0.2585 & -0.2908 & -0.4669 & 0.1272 \\
D5 (PE) & 0.0008 & 0.0567 & 0.0313 & 0.0003 & 0.3555 \\
D6 (TA) & -0.3695 & -0.4592 & -0.2429 & -0.3947 & 0.0077 \\
& 0.0055 & 0.0004 & 0.074 & 0.0029 & 0.4442 \\
\hline
\end{tabular}

P-values obtained by the Sperman correlation coefficient. Significant results in bold.

Note: PAP: Practical Activity Performance; PC: Professional Communication; TM: Time Management; E: Environment; PE: Professional Education; TA: Theoretical Activity.

The analysis between the semesters showed a significant Practical Activity Performance(D1) and Professional Education difference in relation to the psychological, social and environment domains. For stress, there was a significant difference for the

(D5) domains. The ninth semester showed worse sleep quality compared to students in the tenth semester (Table 3).

Table 3 - Comparison between groups of students per semester in relation to quality of life, sleep and stress scores - Poços de Caldas, MG, Brazil, 2018.

\begin{tabular}{|c|c|c|c|c|c|c|c|c|c|}
\hline Variable & & Semester & $\mathbf{n}$ & Mean & sd & Minimum & Median & Maximum & p-value \\
\hline \multirow{8}{*}{$\begin{array}{l}\text { WHOQOL-bref } \\
\text { Domains }\end{array}$} & \multirow{2}{*}{ Physical } & 9 & 25 & 69.4 & 13.3 & 46.4 & 67.8 & 96.4 & \multirow{2}{*}{$0.1025^{* *}$} \\
\hline & & 10 & 30 & 74.4 & 12.2 & 42.8 & 75.0 & 96.4 & \\
\hline & \multirow{2}{*}{ Psychological } & 9 & 25 & 64.0 & 12.1 & 41.6 & 66.6 & 87.5 & \multirow{2}{*}{$0.0447^{*}$} \\
\hline & & 10 & 30 & 71.5 & 14.5 & 37.5 & 75.0 & 95.8 & \\
\hline & \multirow{2}{*}{ Social } & 9 & 25 & 60.3 & 17.3 & 25.0 & 58.3 & 91.9 & \multirow{2}{*}{$0.0405^{*}$} \\
\hline & & 10 & 30 & 70.8 & 19.3 & 25.0 & 75.0 & 100.0 & \\
\hline & \multirow{2}{*}{ Environment } & 9 & 25 & 57.7 & 9.0 & 40.6 & 56.2 & 84.3 & \multirow{2}{*}{$0.0041^{* *}$} \\
\hline & & 10 & 30 & 64.4 & 11.5 & 37.5 & 65.6 & 84.3 & \\
\hline \multirow{12}{*}{ ASNS Domains } & \multirow{2}{*}{ D1 (PAP) } & 9 & 25 & 10.8 & 3.0 & 6.0 & 11.0 & 17.0 & \multirow{2}{*}{$0.0477^{* *}$} \\
\hline & & 10 & 30 & 9.3 & 2.7 & 5.0 & 9.0 & 16.0 & \\
\hline & \multirow{2}{*}{ D2 (PC) } & 9 & 25 & 6.4 & 2.0 & 3.0 & 6.0 & 11.0 & \multirow{2}{*}{$0.1327^{* *}$} \\
\hline & & 10 & 30 & 5.7 & 2.1 & 3.0 & 5.5 & 12.0 & \\
\hline & \multirow{2}{*}{ D3 (TM) } & 9 & 25 & 10.0 & 3.1 & 5.0 & 10.0 & 15.0 & \multirow{2}{*}{$0.0997^{*}$} \\
\hline & & 10 & 30 & 8.5 & 3.4 & 2.0 & 8.0 & 14.0 & \\
\hline & \multirow{2}{*}{ D4 (E) } & 9 & 25 & 6.7 & 3.4 & 1.0 & 6.0 & 12.0 & \multirow{2}{*}{$0.1847^{* *}$} \\
\hline & & 10 & 30 & 5.5 & 3.3 & 0.0 & 5.0 & 12.0 & \\
\hline & \multirow{2}{*}{ D5 (PE) } & 9 & 25 & 11.8 & 3.5 & 6.0 & 12.0 & 18.0 & \multirow{2}{*}{$0.2320 *$} \\
\hline & & 10 & 30 & 10.6 & 3.6 & 6.0 & 10.0 & 18.0 & \\
\hline & \multirow{2}{*}{ D6 (TA) } & 9 & 25 & 9.2 & 2.0 & 5.0 & 9.0 & 13.0 & \multirow{2}{*}{$0.0307^{*}$} \\
\hline & & 10 & 30 & 7.9 & 2.2 & 5.0 & 9.0 & 13.0 & \\
\hline \multirow{2}{*}{ PSQI score } & & 9 & 25 & 8.4 & 3.0 & 1.0 & 8.0 & 16.0 & \multirow{2}{*}{$0.0268^{* *}$} \\
\hline & & 10 & 30 & 6.1 & 3.7 & 0.0 & 5.5 & 12.0 & \\
\hline
\end{tabular}

*p-value obtained by the non-paired Student's t-test.

**p-value obtained by the Mann-Whitney test.

Note: PAP: Practical Activity Performance; PC: Professional Communication; TM: Time Management; E: Environment; PE: Professional Education; TA: Theoretical Activity.

In the comparisons among students regarding the preASNS domains, PSQI score and the physical domain of sence of insomnia, there was a significant difference for most quality of life (Table 4). 
Table 4 - Comparison between groups of students by reports of insomnia in relation to quality of life, sleep and stress scores - Poços de Caldas, MG, Brazil, 2018.

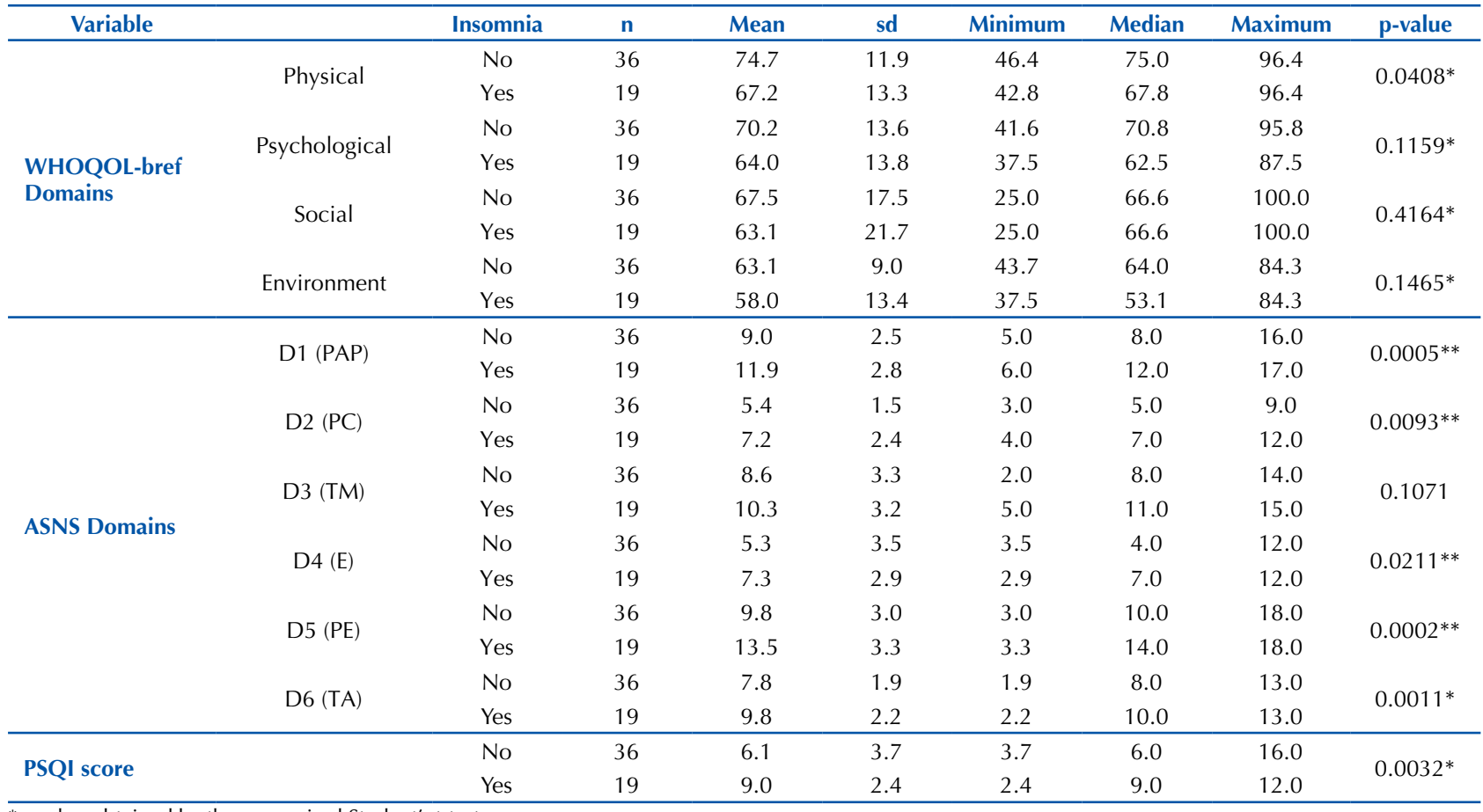

*p-value obtained by the non-paired Student's t-test.

**p-value obtained by the Mann-Whitney test.

Note: PAP: Practical Activity Performance; PC: Professional Communication; TM: Time Management; E: Environment; PE: Professional Education; TA: Theoretical Activity.

However, there was no significant association between insomnia and employment $(\mathrm{p}=0.7486)$ by the Fisher's exact test, or for the work shift $(\mathrm{p}=0.2604)$ by the Chisquared test.

Having children was negatively associated with the Environment (D4) domain of the ASNS. There was a significant difference between the genders regarding the practical activity performance (D1) $(p=0.0469)$ and professional training (D5) ( $p=0.0263$ ) domains using the Mann-Whitney test. Women were more exposed to these stressors.

The Mann-Whitney test showed a significant difference for the following ASNS domains regarding the practice of physical activity: Professional Training (D5) $(\mathrm{p}=0.0025)$ and Theoretical Activity (D6) ( $\mathrm{p}=0.0180)$.

There was no significant difference in the comparison tests in relation to the other sociodemographic data involving the marital status, leisure activity and use of alcohol variables in relation to the ASNS domains, the WHOQOL or the PSQI.

\section{DISCUSSION}

Statistical analyzes revealed a relationship between academic stress factors, poor sleep and changes in quality of life. In addition, students in the ninth semester showed greater exposure to stressors, worse quality of sleep and life. Having insomnia, female gender, not having children and not practicing physical activity were variables which were associated with greater exposure to stress factors.

The Time Management domain (D3) was the domain with the greatest potential for triggering stress and was associated with poor sleep quality and impaired quality of life in the physical, psychological and environmental aspects. It should also be noted that the Practical Activity Performance (D1), Professional Communication (D2), Environment (D4), Professional Education (D5) and Theoretical Activity (D6) domains also represented factors of exposure to stress and were associated to a decrease in scores of students' quality of sleep and life.

Thus, students had greater exposure to factors related to the temporal organization of academic, family, daily, social activities and presented difficulties in reconciling theory and practice, executing care procedures, communication with health professionals in the internship field, concern about the job market and the responsibilities of future professional life, all in a moderate magnitude ${ }^{(17)}$.

Brazilian research data showed that the Professional Education (52.2\%), Professional Communication (33.3\%) and Time Management (32.4\%) domains respectively represented a very high level of stress among Nursing students ${ }^{(20)}$, in addition to a lack of knowledge/skills in practical activities $^{(4)}$. International studies have found similar results in which the greatest stressors were the overload of activities and work, stressors of relationships with colleagues, daily life and those related to patient care ${ }^{(7-9)}$.

Regarding exposure to stress factors, it was found that students in the ninth semester had greater exposure potential to factors related to Practical Activity Performance (D1) and Theoretical Activity (D6), worse sleep quality and lower scores for quality of life in the psychological, social and environment domains. These results can be explained by the insertion of students in the care practice, emphasizing that introducing the students into these activities can 
intensify the stressful situations they experience during their internship ${ }^{(4)}$.

In addition, students with insomnia had worse sleep quality, greater exposure to most domains of the stress assessment instrument, as well as worse quality of life for the physical domain. A study carried out at a university in Spain, which determined the adapted version of an instrument for assessing stress in university students, showed that high levels of stress were associated with a few hours of sleep and worse academic results, among other factors ${ }^{(12)}$.

On the other hand, insomnia was not associated with a double shift (work-study) or night shift, diverging from Brazilian studies which demonstrated that students who perform study/work functions reported insomnia, among other symptoms ${ }^{(6)}$. Perhaps these findings could be better clarified by assessing the profile/preference of the chronotype with the period of work/study.

For the quality of life data, there was a decrease in scores for the physical, psychological and environment domains. A study with 351 nursing students showed similar results, with low perception of quality of life for the same domains identified in this study, as well as for the domain related to social relationships ${ }^{(21)}$.

It is important to note that some sociodemographic characteristics were associated with stress factors in the training environment. In this sense, it was found that women were more concerned with factors related to care procedures and situations they could experience in their future professional lives, while students who did not have children had greater potential for exposure to environmental situations, such as the distance between their house and internship locations, and aspects related to public transport.

Regarding these variables, a study developed in a private institution in the state of Ceará, Brazil with students of the first, third and last years of the undergraduate Nursing course showed that women and students in the last year had a greater chance of presenting stress, as well as in the results of this study. However, a different result was obtained in relation to the child variable, identifying that students with children were more prone to stress $^{(22)}$.

The socio-demographic variables, employment activity and night shift were not associated with poor sleep quality, despite the great majority of students working and allocated in the night shift (Table 1). This data differs from those presented by a Brazilian study ${ }^{(6)}$. This could be related to different aspects of daily work, satisfaction with the work shift or agreement of the chronotype with work/study shift, therefore deserving future investigations which could deepen these aspects.
Although there is an increase in the dissemination of benefits regarding the practice of physical activities for life habits, it was found that $61.8 \%$ of the students did not practice any physical activity, but did leisure activities (72.7\%). These results corroborate a study carried out with 705 Nursing students from three public institutions and a private institution ${ }^{(23)}$.

In relation to the limitations, this is a cross-sectional study which did not evaluate cause and effect, but indicates concern about the stress factors of the training environment and the repercussions of these factors on sleep and the quality of life of the studied population. Second, this study was only conducted with Nursing students in the last year of their undergraduate course at a private higher education institution, therefore, these studies must be prospectively validated in university students from public institutions and in different academic sectors.

\section{CONCLUSION}

Students were exposed to several stress factors in the university environment, with Time Management (D3) being the factor which was related to the greatest potential for triggering stress and associated with poor sleep quality and decreased quality of life in the physical, psychological and environmental dimension aspects.

Students in the ninth semester had greater exposure to stress factors, worse quality of sleep and life. Having insomnia, being female, not having children and not practicing physical activity were sociodemographic characteristics which were associated with greater exposure to stress factors.

In view of this evidence, it is necessary to implement health promotion strategies which can welcome the students. Actions with a focus on the factors with the greatest potential for stress in the internship field are suggested.

Furthermore, low-cost strategies are recommended, such as information booklets on stress, sleep, preventive measures and recommendations for good sleep habits, in addition to implementing actions with the participation of other professionals of the institution who can develop activities such as physical activity and relaxation techniques.

The participation of teachers and the institution is important in order to obtain effective results to reduce possible harmful impacts on the development of academic activities, clinical practice and future professional life.

Finally, the early identification of factors which trigger stress in students in their last year of the undergraduate nursing course, as well as their specificities, can contribute to better organization of Nursing courses, focusing on the academic environment so that it becomes more productive and less stressful for students who will soon be working as nurses.

\section{RESUMO}

Objetivo: Identificar os fatores de estresse do ambiente universitário e as repercussões na qualidade de sono e de vida de estudantes do último ano da graduação em Enfermagem. Método: Estudo transversal, comparativo, quantitativo, realizado com estudantes do último ano da graduação em Enfermagem de uma instituição particular no sul de Minas Gerais. Aplicaram-se, para a coleta de dados, a Escala para Avaliação de Estresse em Estudantes de Enfermagem, o Índice de Qualidade do Sono de Pittsburgh, o questionário de qualidade de vida WHOQOL-bref e o questionário de caracterização sociodemográfica. Para a análise dos dados, foram realizados testes de associação, comparação e de coeficiente de correlação e estatística descritiva. Resultados: A amostra foi de 55 participantes. Houve correlação forte entre o Gerenciamento do Tempo do estresse com o sono e os domínios físico, psicológico e de ambiente da qualidade 
de vida, além da associação significante para insônia e algumas variáveis sociodemográficas. Conclusão: Fatores de estresse associaramse ao sono de má qualidade e a alterações da qualidade de vida. O Gerenciamento de Tempo foi o fator de maior potencialidade para o estresse. O nono semestre teve maior exposição aos fatores de estresse, pior qualidade de sono e de vida.

\section{DESCRITORES}

Estudantes de Enfermagem; Estresse Psicológico; Sono; Qualidade de Vida.

\section{RESUMEN}

Objetivo: Identificar los factores de estrés del ambiente universitario y las repercusiones en la calidad del sueño y de vida de los estudiantes del ultimo año de la graduación de Enfermeria. Método: Estudio transversal, comparativo, cuantitativo, realizado con estudiantes del ultimo año de la graduación de Enfermeria de una institución particular al sur de Minas Gerais. Se aplicaron para a recolección de datos la Escala para Evaluación del Estrés en Estudiantes de Enfermeria, el Indice de la Calidad del Sueño de Pittsburgh, el Cuestionario de la calidad de vida WHOQOL-bref y el Cuestionario de la caracterización sociodemografica. Para el análisis de los datos fueron realizados testes de asociación, comparación y de coeficiente de correlación y estadística descriptiva. Resultados: Muestra de 55 participantes. Hube correlación fuerte entre la Gestión del Tiempo del estrés con el sueño y los domínios físico, psicologico y del ambiente de la calidad de vida, mas allá de la asociación significante para el insomnio y algunas variables sociodemograficas. Conclusión: Factores de estrés se asociaran al sueño de mala calidad y la alteración de la calidad de vida. La Gestión del Tiempo fue el factor de mayor potencialidad para el estrés. El nono semestre tuve mayor exposición a factores de estrés, peor calidad del sueño e de vida.

\section{DESCRIPTORES}

Estudiantes de Enfermería; Estrés Psicológico; Sueño; Calidad de Vida.

\section{REFERENCES}

1. Saleh D, Camart N, Romo L. Predictors of stress in college students. Front Psychol 2017;8:19. DOI: https://doi.org/10.3389/ fpsyg.2017.00019

2. Costa CRB, Oliveira LB, Maynart WHC, Albuquerque MCS, Correia DS. Perceptions of the nursing students on stress-generating factors during the graduation. Rev Rene. 2018;19:e3442. DOI: http://dx.doi.org/10.15253/2175-6783.2018193442

3. Bublitz S, Guido LA, Lopes LFD, Freitas EO. Association between nursing students' academic and sociodemographic characteristics and stress. Texto Contexto - Enferm. 2016;25(4):e2440015. DOI: http://dx.doi.org/10.1590/0104-07072016002440015

4. Hirsch CD, Barlem ELD, Tomaschewski-Barlem JG, Lunardi VL, Oliveira ACC. Predictors of stress and coping strategies adopted by nursing students. Acta Paul Enferm. 2015;28(3):224-9. DOI: http://dx.doi.org/10.1590/1982-0194201500038

5. Almeida LY, Carrer MO, Souza J, Pillon SC. Evaluation of social support and stress in nursing students. Rev Esc Enferm USP. 2018;52:e03405 DOI: http://dx.doi.org/10.1590/s1980-220X2017045703405

6. Santos TCMM, Martino MMF, Sonati JG, Faria AL, Nascimento EFA. Sleep quality and chronotype of nursing students. Acta Paul Enferm. 2016;29(6):658-63. DOI: http://dx.doi.org/10.1590/1982-0194201600092

7. Zhao FF, Lei XL, He W, Gu YH, Li DW. The study of perceived stress, coping strategy and self-efficacy of Chinese undergraduate nursing students in clinical practice. Int J Nurs Pract. 2015;21(4):401-9. DOI: https://doi.org/10.1111/ijn.12273

8. Pai HC. The effect of a self-reflection and insight program on the nursing competence of nursing students: a longitudinal study. J Prof Nurs. 2015;31(5):424-31. DOI: https://doi.org/10.1016/j.profnurs.2015.03.003

9. Eng CJ, Pai HC. Determinants of nursing competence of nursing students in Taiwan: the role of sef-reflection and insight. Nurse Educ Today. 2015;35(3):450-5. DOI: https://doi.org/10.1016/j.nedt.2014.11.021

10. Riley JM, Collins D, Collins J. Nursing student's commitment and the mediating effect of stress. Nurse Educ Today. 2019;76:172-7. DOI: https://doi.org/10.1016/j.nedt.2019.01.018

11. Mota NIF, Alves ERP, Leite GO, Sousa BSMA, Ferreira Filha MO, Dias MD. Stress among nursing students at a public university. SMAD Rev Eletr Saúde Mental Álcool Drog [Internet]. 2016 [cited 2018 Jan 29];12(3):163-70. Available from: http://pepsic.bvsalud.org/pdf/ $\mathrm{smad} / \mathrm{v} 12 \mathrm{n} 3 / 05 . \mathrm{pdf}$

12. Simonelli-Muñoz AJ, Balanza S, Rivera-Caravaca JM, Vera-Catalán T, Lorente AM, Gallego-Gómez JI. Reliability and validity of the student stress inventory-stress manifestations questionnaire and its association with personal and academic factors in university students. Nurse Educ Today. 2018;64:156-60. DOI: https://doi.org/10.1016/j.nedt.2018.02.019

13. Bartlett ML, Taylor H, Nelson JD. Comparison of mental health characteristics and stress between baccalaureate nursing students and non-nursing students. J Nurs Educ. 2016;55(2):87-90. DOI: https://doi.org/10.3928/01484834-20160114-05

14. Freitas AMC, Bárbara JFRS, Vale PRLF, Carvalho SS, Carvalho LF, Nery GS. Percepções de estudantes de enfermagem referente à qualidade de vida na trajetória acadêmica. Rev Enferm UFSM. 2017;7(2):152-66. DOI: http://dx.doi.org/10.5902/2179769225391

15. Lara Flores N, Saldana Balmori Y, Fernandez Vera N, Delgadillo Gutierrez HJ. Salud, calidad de vida y entorno universitario en estudiantes mexicanos de una universidad pública. Hacia Promoc Salud. 2015;20(2):102-17. DOI: http://dx.doi.org/10.17151/hpsal.2015.20.2.8

16. Torres GCS, Paragas ED Jr. Social determinants associated with the quality of life of baccalaureate nursing students: a cross-sectional study. Nurs Forum. 2019;54(2):137-43. DOI: https://doi.org/10.1111/nuf.12306

17. Costa ALS, Polak C. Construction and validation of an instrument for the assessment of stress among nursing students. Rev Esc Enferm USP 2009;43(n.spe):1017-26. DOI: http://dx.doi.org/10.1590/S0080-62342009000500005

18. Bertolazi AN, Fagondes SC, Hoff LS, Dartora EG, Miozzo ICS, Barba MEF, et al. Validation of the Brazilian Portuguese version of the Pittsburgh Sleep Quality Index. Sleep Med. 2011;12(1):70-5. DOI: https://doi.org/10.1016/j.sleep.2010.04.020

19. Bampi LNS, Baraldi S, Guilhem D, Pompeu RB, Campos ACO. Nursing undergraduate students' perception of quality of life. Rev Gaúcha Enferm. 2013;34(1):125-32. DOI: http://dx.doi.org/10.1590/S1983-14472013000200016 
20. Souza VS, Costa MAR, Rodrigues AC, Bevilaqua JF, Inoue KC, Oliveira JLC, et al. Stress among nursing undergraduate students of a brazilian public university. Invest Educ Enferm. 2016; 34(3):518-27. DOI: 10.17533/udea.iee.v34n3a11

21. Gonçalves MM, Fonseca NRS, Carreiro DL, Coutinho LTM, Santos JS, Wagner Luiz Coutinho WLM. Associação entre qualidade de vida e trabalho: a percepção de estudantes de graduação em enfermagem. R Bras Qual Vida (Ponta Grossa). 2016;8(2):159-74. DOI: 10.3895/ rbqv.v8n2.3829

22. Cestari VRF, Barbosa IV, Florêncio RS, Pessoa VLMP, Moreira TMM. Stress in nursing students: study on sociodemographic and academic vulnerabilities. Acta Paul Enferm. 2017;30(2):190-6. DOI: http://dx.doi.org/10.1590/19820194201700029

23. Bublitz S, Guido LA, Kirchhof RS, Neves ET, Lopes LFD. Sociodemographic and academic profile of nursing students from four brazilian institutions. Rev Gaúcha Enferm. 2015;36(1)77-83. DOI: http://dx.doi.org/10.1590/1983-1447.2015.01.48836 